\title{
Hyperlysinaemia
}

\section{Harmless inborn error of metabolism?}

\author{
H. H. vAN GELDEREN and H. L. TEIJEMA \\ From the Department of Paediatrics, University Hospital, Leiden, the Netherlands
}

\begin{abstract}
van Gelderen, H. H., and Teijema, H. L. (1973). Archives of Disease in Childhood, 48, 892. Hyperlysinaemia: harmless inborn error of metabolism? In two sibs with hyperlysinaemia caused by lysine-ketoglutarate reductase deficiency the only clinical abnormality found was small stature, which, however, was probably a familial trait not associated with the hyperlysinaemia.

Analysis of the reports of 9 other known cases and our patients suggests that hyperlysinaemia is an innocuous error of metabolism. Bias, introduced by the reasons for which investigations for metabolic errors have been performed, can explain the symptoms mentioned in the reported patients.
\end{abstract}

In most inborn errors of metabolism the relation between brain damage and other clinical features on the one hand and the enzymatic disorder on the other still needs clarification and is sometimes doubtful. This is especially true for the very rare inborn errors. They have usually been recognized during investigations of mentally deficient children, which introduces strong bias as to the symptoms of the disease.

We here describe two sibs with hyperlysinaemia who do not seem actually to suffer from this disease.

\section{Clinical and laboratory investigations}

The first patient was born 24 August 1964. This boy was referred by the school physician because of small stature. The parents had no complaints about their son and would not have consulted a doctor if they had not been referred. During routine investigation in the outpatient clinic of the Department of Endocrinology (Dr. H. de Vries) lysinuria was suspected on qualitative chromatography of a urine sample. He then was referred to our department.

The boy was then 6.8 years old and, apart from his small stature $(101 \mathrm{~cm}, 13.0 \mathrm{~kg})$, he was healthy and active. IQ was 88; he came from a family of low social class among whom many members had been slow in learning. Birthweight was $2100 \mathrm{~g}$ at term. There had been no significant illnesses in the first years of life. Though he was a small, thin child, his growth rate was within normal limits (subsequent measurements showed growth rate to be $5.6 \mathrm{~cm} / \mathrm{yr}$ between the ages of 5.75 and $\mathbf{7} \cdot 2$ years).

Received 9 May 1973.
Laboratory investigations to find the cause of the patient's hyperlysinuria also revealed hyperlysinaemia. Table I shows the relevant data.

The arginine and ornithine plasma levels are included for a comparison with Colombo's patient with hyperlysinaemia (1971) (see Discussion). In our patient plasma arginine was usually normal, but the ornithine levels were subnormal and decreased when the lysine level was raised by an oral load. This phenomenon might be explained by the fact that lysine can act as an arginase inhibitor, as shown by Hunter and Downs (1945) with in vitro experiments.

Homocitrulline and homoarginine are the products of an alternative pathway in lysine metabolism (Fig. 1). When the main degradative pathway is blocked, these products are present in measurable amounts, in contrast with the normal situation (Colombo, 1971).

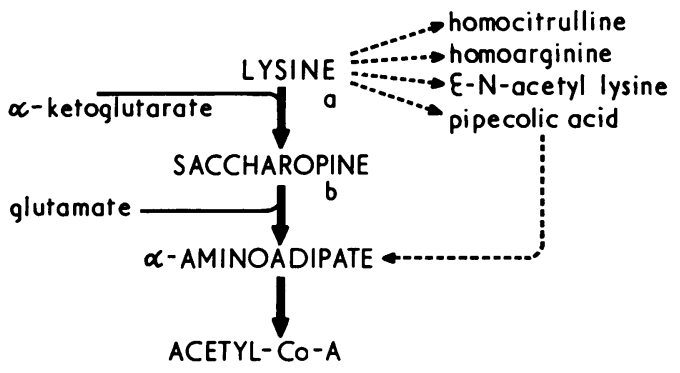

Fig. 1.-Synoptic scheme of lysine degradation. $\rightarrow$ main pathway; - - side paths; a, lysine-ketoglutarate reductase; b, aminoadipic semialdehyde-glutamate reductase. 
Hyperlysinaemia: harmless inborn error of metabolism?

TABLE I

Main laboratory results in patient (hyperlysinaemia)

\begin{tabular}{|c|c|c|c|c|c|c|c|}
\hline & \multicolumn{3}{|c|}{ After overnight fast } & \multicolumn{4}{|c|}{ Oral lysine load $(0.9 \mathrm{mmol} / \mathrm{kg})$} \\
\hline & Free diet & $\begin{array}{c}\text { After 18-day } \\
\text { lysine-free } \\
\text { diet }^{\star}\end{array}$ & $\begin{array}{l}\text { Normal } \\
\text { values }\end{array}$ & $0 \mathrm{hr}$ & $1 \frac{1}{2} \mathrm{hr}$ & $3 \mathrm{hr}$ & $7 \mathrm{hr}$ \\
\hline $\begin{array}{l}\text { Plasma ( } \mu \mathrm{mol} / 1 .) \\
\text { Lysine } \\
\text { Arginine } \\
\text { Homoarginine } \\
\text { Ornithine } \\
\text { Homocitrulline } \\
\text { Urine (mmol/24 hr) } \\
\text { Lysine } \\
\text { Homocitrulline } \\
\text { Homoarginine } \\
\frac{1}{2} \text { cystine } \\
\text { Arginine } \\
\text { Ornithine } \\
\text { 24-hr clearances } \\
\text { (ml/min per } 1 \cdot 73 \mathrm{~m}^{2} \text { ) } \\
\text { Lysine } \\
\text { Cystine } \\
\text { Homoarginine }\end{array}$ & $\begin{array}{ll}788 ; 822 \\
96 ; 68 \\
22 ; 33 \\
15 ; 25 \\
19 \\
\\
\\
4 \cdot 28 \\
0 \cdot 11 \\
0 \cdot 12 \\
0 \cdot 09 \\
0 \cdot 14 \\
0 \cdot 03\end{array}$ & $\begin{array}{l}293 \\
\text { Trace } \\
\text { Trace } \\
\\
0.08 \\
-\overline{0} \\
0.03 \ddagger \\
0.03 \\
0.003 \\
0.003\end{array}$ & $\begin{array}{c}70-150 \\
30-100 \\
0 \\
30-50 \\
0 \\
0.03-0.09 \\
- \\
0.01-0.04 \\
0.004-0.013 \\
0.004-0.014\end{array}$ & $\begin{array}{r}1014 \\
74 \\
21 \\
16 \\
-\end{array}$ & $\begin{array}{r}1548 \\
92 \\
34 \\
14 \\
-\end{array}$ & $\begin{array}{r}1310 \\
73 \\
36 \\
12 \\
-\end{array}$ & $\begin{array}{r}1062 \\
62 \\
-8 \\
-\end{array}$ \\
\hline
\end{tabular}

*Containing $1.54 \mathrm{mmol}$ lysine/day.

†Normal values for plasma from our laboratory; for urine from Hooft et al. (1968); for clearances from Scriver and Davies (1965). $¥$ After 5 days.

As shown in the first column of Table $I$, the urinary excretions of lysine, cystine, and the other basic amino acids are raised when the lysine intake is high. This can be explained by competition for the common reabsorptive tubular site when the plasma lysine exceeds a certain level.

Saccharopine was not present in blood or urine. Therefore, the defective enzyme was assumed to be the lysine-ketoglutarate reductase (Fig. 1). This was confirmed by a study of the activity of this enzyme in the patient's skin fibroblasts (performed by Mr. H. van Someren, Department of Molecular Genetics, University of Leiden).* The experiment was carried out as described by Dancis et al. (1969). After incubation of the fibroblast cells with 14-C-lysine and lysis of the cells (by heating to $100^{\circ} \mathrm{C}$ for 5 minutes), two portions of the lysate were applied to an amino acid analyser column in subsequent runs. In the first run the amino acids were quantified with ninhydrin, whereas in the second run, the saccharopine- or lysine-containing eluates were collected in fractions without ninhydrin for liquid scintillation counting. Those fractions preceeding or succeeding each amino acid peak were used to obtain an average background value for the correction of the measured radioactivity. The $a-\mathrm{NH}_{2}-\mathrm{N}$ content of the lysates was determined and used as a correction factor instead of protein.

Fig. 2 shows the results obtained with the patient's fibroblast cells and with those of a control. The saccharopine fraction of the control fibroblast lysate

*We are grateful to Dr. N. Carson (Belfast) for the gift of saccharopine needed for our study. showed a much higher radioactivity peak than the one obtained in the patient, though in the latter there was still a measurable enzyme activity present. About the same amount of the radioactivity was recovered in the homocitrulline fraction in the experiment with the patient's fibroblasts, whereas in the control experiment this fraction contained no radioactivity at all.

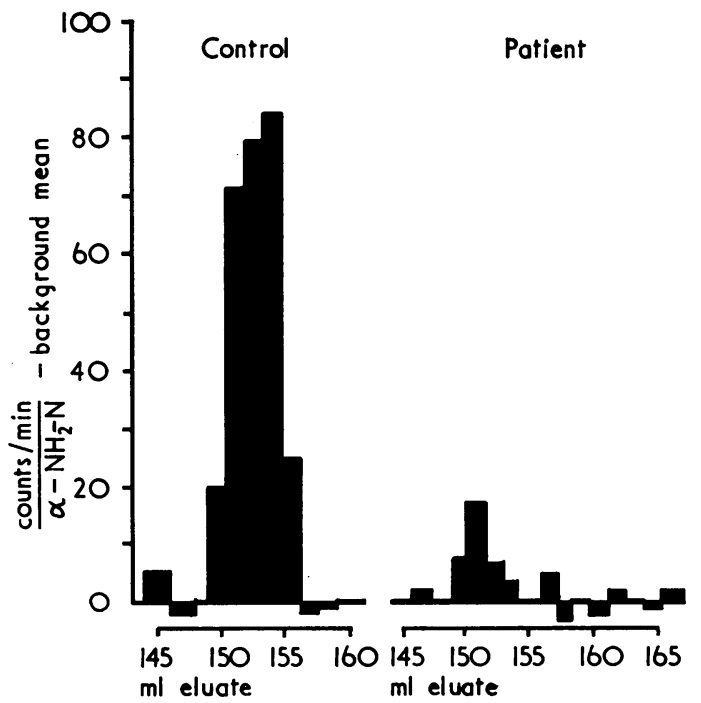

FIG. 2.-Radioactivity recovered in the saccharopine fraction after adding 14-C-lysine to fibroblast culture. 
Presumably the alternative pathway from lysine to homocitrulline was used by the patient's fibroblasts because of the block in the main one.

Table II shows the main laboratory findings in the family. No consanguinity was detected.

\section{TABLE II}

Serum levels of amino acids after overnight fast in patient and his family ( $\mu \mathrm{mol} / \mathrm{l}$.

\begin{tabular}{l|c|c|c|c|c}
\hline & Father & Mother & Sib 1* & Sib 2* & Patient \\
\hline Lysine & 180 & 164 & 749 & 118 & 822 \\
Homoarginine & - & - & 23 & - & 22 \\
\hline
\end{tabular}

${ }^{\star}$ Sisters of patient.

Sib 1 was recognized as another case of hyperlysinaemia. She also had a marked lysinuria in contrast to her parents and her sister. As she had no complaints and co-operation was not easily obtained from the family, no further investigations were performed on her.

Small stature was a common feature in the family and in maternal sibs (Fig. 3). All but one of the mother's

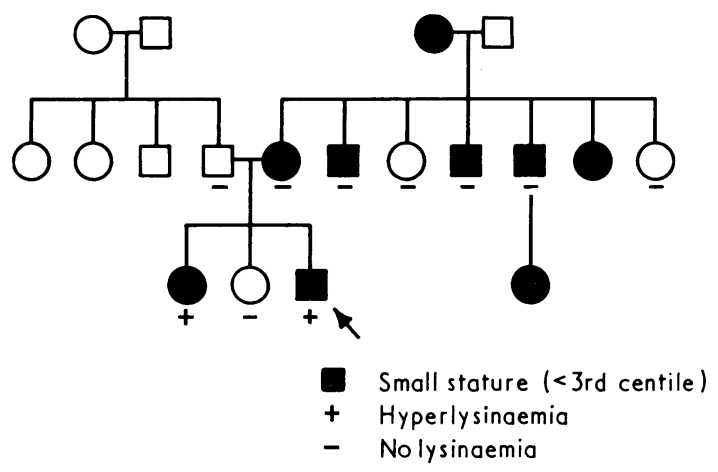

FIG. 3.-Small stature and lysinaemia in family.

sibs have been checked for hyperlysinuria (chromatography of urine samples) but none was found. The small members of the family were otherwise healthy, except for one sister of the mother who suffered from diabetes and heart disease. Growth rates of the two sibs (data from the school health service) showed growth rates within normal limits.

Hydroxyproline levels in our patient were normal $(2.3 \mathrm{mg} / \mathrm{kg}$ per $24 \mathrm{hr})$ and did not change after 18 days of an almost lysine-free diet.

\section{Discussion}

Hyperlysinaemia is defined as an inborn error of metabolism, leading to greatly increased levels of serum lysine. It should not be confused with other hyperaminoacidaemias in which lysine is only one of several amino acids that show high levels, e.g. in liver disease. It is also distinct from the more common hyperlysinurias due to transport defects in the renal tubules, in which blood levels are not increased.

The disease was first described by Woody (1964) and, considering the scarcity of reported cases, it must be rare. Mass screening in 204,000 newborns in Massachusetts resulted in detection of only one case of hyperlysinaemia (Levy, Shih, and McCready, 1971).

Hyperlysinaemia is caused by a block in the main degradation pathway of lysine. This was shown for the first time by Dancis et al. (1969) who found a virtual absence of lysine-ketoglutarate reductase activity, the enzyme responsible for the first step of lysine degradation, i.e. from lysine to saccharopine (Fig. 1). In this type of hyperlysinaemia no saccharopine is found in the urine.

A second cause of hyperlysinaemia, first described by Carson (1969) under the name of saccharopinuria, is a block at a further step in lysine degradation, from saccharopine to $\alpha$-aminoadipic- $\epsilon$-semialdehyde. Decreased activity of the enzyme responsible for this step (aminoadipic semialdehydeglutamate reductase) was recently shown in one case of saccharopinuria by Simell, Johansson, and Aula (1973). In this type the urine contains significant amounts of saccharopine.

The child reported by Armstrong and Robinow (1967) as a case of hyperlysinaemia does not fit the requirements of this diagnosis because plasma lysine levels were either not raised or were only slightly raised while renal clearance of lysine was increased.

The case described by Colombo (1971) is metabolically and clinically different; in addition to hyperlysinaemia, periodic hyperammonaemia and hyperargininaemia were present. The pathway from lysine via saccharopine to $\alpha$-aminoadipic acid was said to be functioning normally. It is clear that this case is different from hyperlysinaemia as defined earlier. The name given by Colombo to this disease is lysine intolerance which seems more apt than hyperlysinaemia.

Table III summarizes the symptoms of 11 cases from 8 families.

It seems likely that mental deficiency is not a feature of hyperlysinaemia. All 4 children who were markedly mentally deficient were detected when screened for a metabolic cause for their mental deficiency. None of the accidentally found cases has been mentally deficient.

As to growth, it is interesting to note that most, but not all, cases have been of small stature. Dautrevaux (1969), reviewing the patients with hyperlysinaemia known at that time, thought growth 
TABLE III

Symptoms in proven cases of hyperlysinaemia

\begin{tabular}{|c|c|c|c|c|c|c|}
\hline Cases reported & Consanguinity & $\begin{array}{l}\text { Mental } \\
\text { defect }\end{array}$ & $\begin{array}{l}\text { Small } \\
\text { stature }\end{array}$ & EEG & Convulsions & Remarks \\
\hline 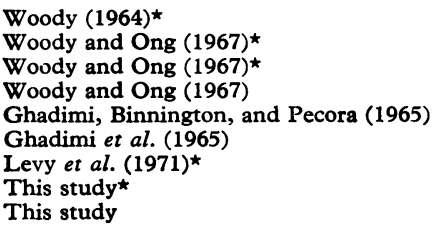 & $\begin{array}{l}\text { Yes } \\
\text { Yes } \\
\text { Yes } \\
? \\
\text { Yes } \\
\text { Yes } \\
? \\
\text { No } \\
\text { No }\end{array}$ & $\begin{array}{l}\text { Yes } \\
\text { No } \\
\text { No } \\
\text { No } \\
\text { Yes } \\
\text { Yes } \\
\text { No } \\
\text { No } \\
\text { No }\end{array}$ & $\begin{array}{l}\text { Yes } \\
\text { No } \\
? \\
? \\
\text { Yes } \\
\text { Yes } \\
\text { No } \\
\text { Yes } \\
\text { Yes }\end{array}$ & $\begin{array}{l}\text { Normal } \\
\text { Normal } \\
? \\
? \\
\text { Abnormal } \\
\text { Abnormal } \\
\text { ? } \\
\text { Abnormal } \\
?\end{array}$ & $\begin{array}{l}\text { Yes } \\
\text { No } \\
? \\
? \\
\text { No } \\
\text { Yes } \\
? \\
\text { No } \\
\text { No }\end{array}$ & $\begin{array}{l}\text { Sibs } \\
\text { Cousin of above }\end{array}$ \\
\hline $\begin{array}{l}\text { Carson (1969) } \\
\text { Simell, Visakorpi, and Donner (1972) }\end{array}$ & $\begin{array}{l}\text { No } \\
\text { Not }\end{array}$ & $\begin{array}{l}\text { Yes } \\
\text { Mild }\end{array}$ & $\begin{array}{l}\text { Yes } \\
\text { No }\end{array}$ & $\begin{array}{l}\text { Abnormal } \\
\text { Normal }\end{array}$ & $\begin{array}{l}\text { No } \\
\text { No }\end{array}$ & $\begin{array}{l}\text { Saccharopinuria } \\
\text { Saccharopinuria }\end{array}$ \\
\hline
\end{tabular}

*Lysine-ketoglutarate reductase deficiency shown.

tFrom an isolate.

retardation was a feature of the disease while he expressed doubt whether mental deficiency in many of the reported cases could be attributed to the hyperlysinaemia. As dwarfism is common in mental deficiency, the retarded growth in Cases 1, 5, 6 , and 8 need not be causally related to hyperlysinaemia. Case 5 was hypothyreotic. In our cases (10 and 11) it is far more likely that the small stature has a separate genetic basis. As Fig. 2. shows, the small stature seems to be a (dominant) trait, independent of hyperlysinaemia. The normal growth rate in our patients also makes a metabolic cause unlikely.

Convulsions have been reported in only two hyperlysinaemic patients with mental deficiency.

As far as can be concluded from the descriptions of the reported cases, no other abnormalities and no neurological symptoms can be attributed to the hyperlysinaemia as such.

Since treatment for longer periods with a lowlysine diet has not been tried, the effect upon growth is not known. In our patient 18 days of this treatment did not increase hydroxyproline excretion. However, hydroxyproline excretion was normal before treatment.

\section{REFBRENCES}

Armstrong, M. D., and Robinow, M. (1967). A case of hyperlysinemia. Pediatrics, 39, 546.

Carson, N. A. J. (1969). Saccharopinuria: a new inborn error of lysine metabolism. In Enzymopenic Anaemias, Lysosomes and other Papers. Proceedings of the 6th Symposium of the Society for the Study of Inhorn Errors of Metabolism, p. 163. Ed. by J. D. Allan, K. S. Holt, J. T. Ireland, and R. J. Pollitt. Livingstone, Edinburgh.

Colombo, J. P. (1971). Congenital Disorders of the Urea Cycle and Ammonia Detoxication, p. 123. Karger, Basle.

Dancis, J., Hutzler, J., Cox, R. P., and Woody, N. C. (1969). Familial hyperlysinemia with lysine-ketoglutarate reductase insufficiency. Fournal of Clinical Investigation, 48, 1447.

Dautrevaux, M. (1969). L'hyperlysinémie. In Actualités Métaboliques en Pédiatrie, 3rd séries, p. 371 . Ed. by A. G. Fontaine. Editions Doin, Deren et Cie, Paris.

Ghadimi, H., Binnington, V. I., and Pecora, P. (1965). Hyperlysinemia, associated with retardation. New England fournal of Medicine, 273, 723.

Hooft, C., Carton, D., Snoeck, J., Timmermans, J., Antener, I., Hende, C. van den, and Oyaert, W. (1968). Further investigations in the methionine malabsorption syndrome. Helvetica Paediatrica Acta, 23, 334.

Hunter, A., and Downs, C. E. (1945). The inhibition of arginase by amino-acids. Fournal of Biological Chemistry, 157, 427

Levy, H. L., Shih, V. E., and McCready, R. A. (1971). Inborn errors of metabolism and transport: prenatal and neonatal diagnosis. Abstract XIII International Congress of Pediatrics, Part V, 1, p. 1, Vienna.

Scriver, C. R., and Davies, E. (1965). Endogenous renal clearance rates of free amino acids in pre-pubertal children. Pediatrics, 36, 592 .

Simell, O., Johansson, T., and Aula, P. (1973). Enzyme defect in saccharopinuria. Fournal of Pediatrics, 82, 54.

Simell, O., Visakorpi, J. K., and Donner, M. (1972). Saccharopinuria. Archives of Disease in Childhood, 47, 52.

Woody, N. C. (1964). Hyperlysinemia. American fournal of Diseases of Children, 108, 543.

Woody, N. C., and Ong, E. B. (1967). Paths of lysine degradation in patients with hyperlysinemia. Pediatrics, 40, 986.

Correspondence to Professor H. H. van Gelderen, Academisch Ziekenhuis-Leiden, Rijnsburgerweg 10, Leiden, The Netherlands. 